\title{
VERBA BANTU BENEFAKTIF TEKURERU DAN TEMORAU DALAM KALIMAT BAHASA JEPANG
}

\author{
Sri Iriantini \\ Maranatha Christian University \\ iriantinisri3@gmail.com
}

\begin{abstract}
Abstrak
Artikel ini bertujuan untuk membahas konstruksi benefaktif dalam bahasa Jepang, khususnya bentuk verba bantu te kureru dan te morau. Verba benefaktif dalam bahasa Jepang dikenal dengan istilah yari-morai (memberi dan menerima). Verba ini memiliki tujuh varian dan digunakan untuk menunjukkan adanya suatu benefit yang diberikan dan diterima oleh seseorang dari suatu tindakan atau peristiwa yang dijelaskan dalam kalimat. Dalam bahasa lain, bentuk benefaktif ini dapat terlihat dan diamati dari sisi semantisnya, tetapi secara sintaksis dan morfolgis mungkin bisa saja menggunakan satu verba yang sama dengan bentuk kausatif, seperti verba 'membetulkan' dalam bahasa Indonesia. Verba-verba benefaktif yarimorai ini dapat juga digunakan bersama-sama dengan verba inti sebagai verba bantu atau hojodoushi, dengan mengubahnya terlebih dahulu ke dalam bentuk te, misalnya te kureru dan te morau. Berdasarkan analisis data yang diambil dari buku-buku berbahasa Jepang, ditemukan bahwa keduanya ini secara sintaksis dan semantis mempunyai beberapa persamaan dan perbedaan.
\end{abstract}

Kata Kunci: Verba benefaktif yarimorai, bentuk benefaktif tekureru-temorau, analisis sintaksis dan semantis.

\begin{abstract}
This article aims to discuss the benefactive construction in Japanese language, particularly the auxiliary forms known as 'te kureru' and 'te morau'. In Japanese language, benefactive verbs are known as 'yarimorai' (givng-receiving). They are a set of seven verbs and used to suggest that the action or event described in a sentence has a certain beneficial effect on the recipient. However, unlike other languages in general, benevactives in Japanese are not only indicated semantically and pragmatically, but they also occur at syntactic and morphological levels. For example, in Bahasa Indonesia, the verb 'membetulkan' can be used interchangeably for both benefactive and causative constructions. But the Japanese benefactive system is more complex than that. Benevactives in Japanese can be used either as main verbs or auxiliary verbs, which are called 'hojodoushi' by changing the form to 'te kureru' and 'te morau'. Based on the analysis of linguistic data taken from various books in Japanese, both forms share syntactic and semantic similarities and differences.
\end{abstract}

Keywords: Benefactive verb yarimorai, benefactive forms tekureru and temorau, syntactic and semantic anaysis.

\section{PENDAHULUAN}

Bahasa Jepang mempunyai verba yarimorai 'memberi' dan 'menerima' yang penggunaannya berbeda dengan penggunaan verba memberi dan menerima dalam bahasa lain pada umumnya. Verba memberi-menerima dalam bahasa Jepang selain dapat digunakan sebagai verba inti yang mengisi fungsi predikat dalam kalimat, juga dapat pula digunakan sebagai verba bantu 
(auxiliary verb) yang dilekatkan dengan verba inti untuk menambahkan makna pada verba inti tersebut. Perhatikan contoh berikut.

(1) 太郎 は 私 にプレゼントをくれた。

Tarou wa watashi ni purezento o kureta

Tarou Top saya Ben kado Akus memberi

'Tarou memberikan kado kepada saya'

Pada kalimat (1) terdapat verba memberi kureru dalam bentuk informal lampau menjadi kureta yang digunakan sebagai verba inti yang mengisi fungsi predikat dalam kalimat tersebut. Kureru termasuk verba memberi yang menunjukkan adanya peralihan benda, dalam kalimat (1) yaitu purezento 'kado' yang berpindah tempat dari Tarou sebagai pemberi kepada watashi 'saya', dalam hal ini pembicara sebagai penerima benda. Verba memberi kureru dalam bahasa Jepang digunakan jika pembicara berposisi sebagai penerima, dan pemberi yang merupakan pelaku aktivitas dijadikan sebagai subjek/ topik dalam kalimat tersebut. Adanya verba memberi kureru inilah yang membedakan bahasa Jepang dengan bahasa-bahasa lainnya dalam hal penggunaan verba memberimenerima.

\section{(2) 太郎 は 私 にプレゼント を 買ってくれた。 Tarou wa watashi ni purezento o kattekureta \\ Tarou Top saya Ben kado Akus membeli memberi lampau 'Tarou membelikan kado untuk saya'.}

Pada kalimat (2) verba memberi kureru melekat pada verba inti kau 'membeli' dalam bentuk sambung menjadi katte, menjadi kattekureta. Verba memberi kureru pada kalimat (2) ini bukan sebagai verba inti tetapi sebagai verba bantu (auxiliary verb) yang menambahkan makna pada verba inti kau 'membeli'. Oleh karena itu, makna yang kuat muncul adalah makna verba inti, sehingga jika diterjemahkan ke dalam bahasa lainnya termasuk bahasa Indonesia, mungkin saja makna verba memberi kurerunya hilang diganti dengan makna imbuhan yang melekat dengan verba intinya dengan makna yang sama dengan verba memberi kureru. Dengan demikian jika kalimat tersebut diterjemahkan ke dalam bahasa Indonesia menjadi ‘Tarou membelikan kado (untuk) saya'. Imbuhan me-kan dalam bahasa Indonesia dapat menggantikan verba memberi kureru dalam kalimat ini. Tarou berbaik hati telah membelikan kado untuk saya, dalam hal ini sebagai pembicara sekaligus penerima. Pemberi yaitu Tarou diletakkan sebagai subjek/topik kalimat.

Seperti yang terlihat pada contoh (1) dan (2) verba memberi-menerima dalam bahasa Jepang yang terdiri dari verba yaru, ageru, sashiageru, kureru, kudasaru, morau, dan itadaku, semuanya dapat digunakan sebagai verba inti yang mengisi fungsi predikat dalam sebuah kalimat, dan dapat juga digunakan sebagai verba bantu hojodoushi (auxiliary verb) yang mungkin saja makna memberi-menerimanya tidak akan kelihatan dengan jelas dibanding verba inti 
yang dilekati verba memberi-menerima tersebut. Akan tetapi, dari semua verba memberi-menerima tersebut yang akan dibahas di sini adalah verba memberi kureru dan verba menerima morau dalam fungsinya sebagai verba bantu hojodoushi. Hal ini disebabkan karena keduanya menunjukkan hal penerimaan sesuatu dari seseorang kepada seseorang, tetapi berbeda dari sudut pandang (viewpoint) pembicaranya. Selain itu, akan dibahas pula apakah berkaitan dengan suatu kebaikan seseorang terhadap orang lainnya, atau benefit yang diberikan ataukah diterima seseorang, ataukah tidak.

Mengenai verba memberi menerima ini, Kuno (1973: 127) menjelaskannya sebagai berikut: In conventional grammars, typical explanations of giving and receiving verbs kureru, kudasaru, yaru, ageru, sashiageru, morau, itadaku, etc. proceed as follows:

(1) yaru : someone gives something to a person equal or inferior to him ageru : someone gives something to a person superior to him kureru : someone equal or inferior to the speaker gives something to him morau : someone receives something from a person equal to or inferior to him itadaku : someone receives something from a person superior to him, etc.

Dalam tata bahasa tradisional, penjelasan secara tipikal dari verba-verba memberi dan menerima 'kureru, kudasaru, yaru, ageru, sashiageru, morau, itadaku', dan lain-lain, adalah sebagai berikut:

a. yaru : seseorang memberikan sesuatu kepada orang yang sederajat atau lebih rendah dari dirinya (pemberi).

ageru : seseorang memberikan sesuatu kepada seseorang yang lebih tinggi derajatnya dibanding dirinya.

kureru : seseorang yang sederajat atau derajatnya lebih rendah dari pembicara memberikan sesuatu kepada dia (pembicara)

morau : seseorang menerima sesuatu dari orang lain yang sederajat atau lebih rendah dari dirinya.

Itadaku : seseorang menerima sesuatu dari orang lain yang lebih tinggi derajatnya dibanding dirinya, dll.

Dalam kutipan tersebut Kuno menjelaskan bahwa dalam gramatika tradisional, verba-verba memberi dan menerima dalam bahasa Jepang dalam penggunaannya harus memperhatikan hubungan antara pemberi dan penerima, apakah sederajat lebih rendah, ataukah lebih tinggi.

Kemudian Kuno (1973: 127) menambahkannya sebagai berikut: ...that not only the concept of the speaker but also that of someone who belongs to the speaker plays a distinctive role in the use of some of these verbs

Dengan demikian, penggunaan verba memberi dan menerima tidak hanya melibatkan konsep tentang pembicara (the speaker) tetapi juga konsep bahwa apakah seseorang itu merupakan orang-orang yang dekat dengan pembicara pun, berperan dalam membedakan penggunaan dari verba-verba tersebut. Perhatikan contoh kalimat berikut: 
b. (1) Maryga boku ni konohon o kureta.

Nom saya kepada ini buku akus memberi(kan)

'Mary (telah) memberi saya buku ini'.

(Mary telah memberikan buku ini kepada saya).

(2) Maryga otouto ni konohon o kureta

Nom adik laki2 kepada ini buku akus memberi(kan)

'Mary telah memberi adik laki-laki saya buku ini'.

(Mary telah memberikan buku ini kepada adik laki-laki saya.)

(3) *Mary ga otouto ni kono hon o kureta.

'Mary telah memberikan buku ini kepada adik laki-lakinya'.

(4) *Mary ga John ni kono hon o kureta.

'Mary telah memberikan buku ini kepada John'.

Dari contoh kalimat $b(1)$ sampai $b(4)$, kalimat $b(3)$ dan $b(4)$ merupakan kalimat yang tidak berterima secara semantik, karena pada kalimat $\mathrm{b}(3)$ kureru tidak bisa digunakan kepada penerima yang masih tergolong kerabat dari pemberi, dan pada kalimat $\mathrm{b}(4)$ kureru tidak bisa digunakan kepada orang lain di luar pembicara sebagai penerima barang tersebut.

Kemudian Tsujimura (1996: 334) menambahkan tentang penggunaan verba memberi menerima ini sebagai berikut:

In Japanese there are several verbs that correspond to the English verbs give and receive, and the distinction among them involves diverse concepts that include the following factors: (i) whether a given transfer is to be described as a giving or receiving event, (ii) where the speaker stands in the giving / receiving event, and (iii) what the social status is of the participants of the giving / receiving event.

Pada kutipan tersebut, Tsujimura mengatakan bahwa dalam bahasa Jepang terdapat verba-verba yang berkorespondensi seperti verba-verba dalam bahasa Inggris 'give' dan 'receive', dan perbedaan diantara verba-verba tersebut bergantung kepada beberapa konsep sebagai berikut : (i) apakah transfer pemberian (pemindahan barang/sesuatu) itu digambarkan sebagai peristiwa pemberian ataukah penerimaan?, (ii) Dimanakah posisi the speaker (pembicara) ketika peristiwa pemberian/penerimaan terjadi?, (iii) Apa status sosial partisipan dalam peristiwa pemberian/penerimaan itu?

Dalam teori Kuno diungkapkan bahwa penggunaan verba memberimenerima dalam bahasa Jepang harus memperhatikan hubungan antara pemberi dan penerima, apakah sederajat, lebih rendah, ataukah lebih tinggi, sudut pandang pembicara, dan apakah partisipan dalam kalimat tersebut dekat dengan pembicara, ataukah penerima. Dan selanjutnya Tsujimura menambahkan bahwa perbedaan penggunaan verba memberi-menerima tersebut bergantung pada apakah transfer / perpindahan benda itu 
digambarkan sebagai sebuah peristiwa pemberian ataukah penerimaan, di manakah posisi pembicara apakah sebagai pemberi ataukah penerima, dan juga harus diperhatikan status sosial partisipan dalam peristiwa pemberian / penerimaan tersebut.

Merujuk ke teori Tsujimura ini, verba bantu memberi tekureru, dan verba bantu temorau dapat dikatakan keduanya merupakan peristiwa penerimaan, hanya berbeda dalam posisi fokus/subjek pembicaraan. Untuk verba bantu menerima temorau, pembicara sebagai penerima dijadikan subjek kalimat, sedangkan untuk verba memberi tekureru, pembicara berposisi sebagai penerima tetapi yang menjadi subjek dalam kalimat tersebut adalah pemberi. Perhatikan contoh berikut ini:

\section{3.太郎さん が いもうとにおかしを買ってくれた。}

Tarou san wa imouto ni okashi o kattekureta.

“Tarou membelikan adik perempuan (saya) sepotong kue'.

Pada kalimat 3 tersebut digunakan verba bantu memberi tekureru dalam bentuk lampau menjadi tekureta yang dilekatkan dengan verba inti kau 'membeli'. Kalimat ini diucapkan oleh penerima sebagai pembicara yang ditandai dengan kata bantu ni, dan merupakan hal penerimaan. Pembicara bukan penerima secara langsung tetapi mewakili orang yang menerima yaitu imouto 'adik perempuan' nya sendiri'. Hal seperti ini sering muncul dalam percakapan seharihari orang Jepang, pembicara bukan penerima secara langsung tetapi mewakili seseorang yang merupakan kerabat dekat yang muncul dalam kalimat tersebut. Pembicara di sini ingin menunjukkan rasa terima kasihnya kepada pemberi dan merasa beruntung mendapat benefit dari pemberi, sehingga penerima menempatkan pemberi sebagai subjek / fokus dalam kalimat yang menggunakan tekureru. Pemberi sebagai pelaku aktivitas 行為者 kouisha ditandai dengan kata bantu ga. Dengan demikian makna dari kalimat 3 ini adalah Tarou membelikan adik perempuan si pembicara kue, tetapi kalimat ini diucapkan oleh pembicara mewakili adik perempuannya.

Sementara itu perhatikan kalimat berikut yang menempatkan penerima sebagai fokus / subjek dalam kalimat / pembicaraan yang ditandai dengan kata bantu joshi ga:

\section{4. 妹 が 太郎さんにおかしをかってもらった。} Imouto ga Tarou ni okashi o kattemoratta

Adik pr Nom Tarou Dat kue Akus membeli menerima(dibelikan) “Adik perempuan (saya) dibelikan (sepotong) kue oleh Tarou'.

Pada kalimat 4 tersebut, digunakan verba bantu menerima temorau dalam bentuk biasa lampau menjadi temoratta. Pelaku aktivitas (行為者 kouisha) atau pemberi ditandai dengan kata bantu joshi ni, dan pembicara sebagai penerima ditandai dengan joshi 'kata bantu' ga. Berbeda dengan kalimat yang menggunakan verba memberi tekureru, kalimat yang menggunakan verba menerima temorau menempatkan penerima sebagai subjek dalam kalimat. Akan tetapi keduanya sama-sama menunjukkan hal 'penerimaan' sesuatu benda atau jasa dari 
seseorang, atau pembicara dalam kalimat yang menggunakan tekureru dan temorau ini merupakan penerima suatu benda, jasa, atau adanya peralihan perasaan. Jika digambarkan dengan bagan sebagai berikut :

\section{与える人 が 受ける人に 対象をくれる・てくれる。 Ataeru hito ga ukeru hito ni taishou o kureru/tekureru (Pemberi) ga (Penerima) ni objek memberi Orang-orang di sekitar pembicara)}

\section{受ける人 が 与える人に 対象 をもらう・てもらう。 Ukeru hito ga ataeru hito ni taishou o morau/temorau Penerima ga pemberi ni objek o menerima}

Dari bagan tersebut terlihat bahwa baik tekureru maupun temorau memfokuskan pada hal penerimaan. Perbedaan terletak pada subjek kalimat, untuk tekureru yang dijadikan subjek kalimat adalah pemberi dan untuk temorau yang dijadikan subjek adalah penerima. Dengan demikian pada kedua kalimat ini mengandung adanya onkei 'kebaikan' dan seseorang yang menerima keuntungan (benefit / benenefisiari). Mengenai hal ini Ito dalam jurnal Nihongogakuronshuu (2010 : 6 (149)) mengemukakan sebagai berikut :

「てくれる」文と「てもらう」文の受益、恩恵を取り上げる際、これ まで両者は同一のものとして扱われることがほとんどであった。

(tekureru) bun to (temorau) bun no jueki, onkei o toriageru sai, koremade ryousha wa douichi no mono toshite atsukawareru koto ga hotondo de atta.

Dalam hal onkei 'kebaikan' dan jueki 'penerimaan benefit', kalimat (tekureru) dan kalimat (temorau) keduanya mempunyai kesamaan, yaitu pembicara merupakan si penerima.

Dengan demikian, dapat dipahami bahwa kalimat yang menggunakan verba bantu memberi tekureru dan verba bantu temorau selalu diungkapkan oleh pembicara/penutur (hanashite). Dan perbedaannya adalah dari fokus pembicaraan dan posisi penutur. Dalam makalah ini akan dibahas perbedaan apa saja selain fokus pembicaraan atau posisi penutur, seperti mengenai onkei 'kebaikan' dan benefit yang diterima, apakah memang sudah sewajarnya, ataukah tidak, kemudian benefit yang diterima apakah langsung diterima oleh penutur ataukah secara tidak langsung.

\section{METODE PENELITIAN}

Metode yang digunakan dalam penelitian ini adalah metode kualitatif dengan penyajian data yang deskriptif. Menurut Djajasudarma (2010: 11), metode kualitatif merupakan metode yang secara fundamental bergantung pada pengamatan manusia dalam kawasannya sendiri dan berhubungan dengan masyarakat tersebut melalui bahasanya, serta peristilahan. Dan karena penelitian ini dilakukan dengan mengamati semua data yang berhubungan 
verba bantu benefaktif tekureru dan temorau yang dihubungkan dengan masyarakat pengguna bahasa tersebut, maka penelitian ini menggunakan metode kualitatif. Selanjutnya hasil pengamatan tersebut dideskripsikan sesuai dengan data alami yang didapatkan. Untuk teknik penelitian yang dilakukan adalah studi kepustakaan dengan mencari hal-hal yang dikaitkan dengan gejalagejala kebahasaan yang muncul yang menimbulkan suatu permasalahan.

\section{HASIL DAN PEMBAHASAN}

Kalimat-kalimat yang menggunakan verba bantu memberi tekureru dan verba bantu menerima temorau memiliki perbedaan secara spesifik terutama yang berkaitan dengan benefit yang diterima oleh pembicara bisa secara langsung dan tidak langsung, dan dalam hal objek aktivitas dengan penerima benefit sama ataukah tidak sama.

\subsection{Kalimat yang menggunakan verba bantu memberi tekureru}

1. 何をしているか 位 は 弟に 話してくれたっていいではないか. (IH:149) Nani o shiteiru ka gurai wa otoutoni hanashite kuretatte ii dewanaika. Apa aku sedang lakukan kira-kira top adik laki2 bicara memberi bagus bukan

Pada kalimat 1 tersebut digunakan verba bantu memberi tekureru yang dilekatkan dengan verba inti / utama hanashite 話して。Dalam kalimat ini 弟 otouto 'adik laki-laki' yang menjadi objek dari aksi perbuatan, dan 私 watashi 'saya' sebagai penerima benefit yang tidak secara langsung sesuai dengan keadaan, karena penerima benefit langsungnya adalah otouto 'adik laki-laki'nya penutur / pembicara yang berada dalam kelompok uchi 'dalam'. Sebetulnya, secara makna, penutur sebagai penerima tidak langsung dalam kalimat tersebut belum mendapatkan benefit dari pemberi lewat otouto 'adik laki-lakinya' tetapi masih mengharapkan kepada pemberi supaya memberi kabar kepadanya yang dikatakan kepada adik laki-lakinya (melalui adik laki-lakinya). Pemberi dalam kalimat ini lesap, tetapi kemungkinannya bisa orang ke- 2 yang diajak bicara / petutur, atau orang ke- 3 yang tidak hadir ketika kalimat tersebut diucapkan. Dan walaupun lesap, dari penggunaan verba bantu memberi tekureru yang digunakan, dapat dipahami bahwa penutur adalah penerima benefit yang diberikan oleh seseorang yang hadir dalam kalimat tersebut dan merupakan salah satu partisipan dalam percakapan tersebut, atau tidak muncul dalam kalimat tersebut, dan tidak hadir ketika percakapan tersebut diungkapkan.

2. 太郎 が 花子 を ほめ \{てやった・てくれた\} (IH:148)

Tarou ga Hanako o home \{teyatta/ tekureta\}

Taro Nom Hanako Akus memuji memberi / memberi

'Taro memuji Hanako'

(Taro memberi pujian kepada Hanako)

Kalimat 2 tersebut menggunakan dua verba bantu memberi yaitu teyaru dan tekureru, yang keduanya dapat digunakan dengan nuansa makna yang 
berbeda. Keduanya dapat digunakan dengan makna yang menunjukkan adanya kebaikan yang diberikan kepada Hanako yaitu sebuah pujian. Untuk kalimat Tarou ga Hanako o hometeyatta, maka penerima kebaikan di sini jelas Hanako, ditandai dengan joshi o, yang diberikan oleh Taro, ditandai dengan joshi ga. Penutur / pembicara merupakan orang ke-3 yang hadir ketika kalimat ini diungkapkan. Dan baik Taro maupun Hanako mungkin saja tidak ada kaitan apapun dengan pembicara/ penutur. Lain halnya jika verba bantu memberi yang digunakan adalah tekureru, menjadi Tarou ga Hanako o hometekureta. Onkei 'kebaikan' secara langsung diterima oleh Hanako, tetapi secara tidak langsung kebaikan itu juga diterima oleh penutur/pembicara, karena Hanako mempunyai kaitan secara uchi (satu kelompok/kerabat) dengan penutur / pembicara.

\section{3. 太郎 が 花子 を ほめてやってくれた。(IH:148) \\ Tarou ga Hanako o homete yatte kureta. \\ Tarou Nom Hanako Akus memuji memberi memberi \\ 'Tarou memuji Hanako (untuk saya)'}

Pada kalimat 3 verba bantu yang digunakan dua yaitu verba bantu memberi teyaru dan tekureru yang dilekatkan pada verba inti homeru. Penggunaan dobel verba bantu memberi/menerima seperti ini biasa dalam bahasa Jepang, tetapi makna yang muncul harus melihat verba bantu memberi / menerima yang digunakan di akhir kalimat. Pada kalimat 3 ini verba bantu di akhir kalimat adalah verba bantu memberi tekureru, berarti yang menerima onkei 'kebaikan' adalah penutur / pembicara, tetapi bukan pujian yang diterima oleh Hanako melainkan karena jasa memuji Tarou yang diberikan pada Hanako sehingga penutur/pembicara merasa terbantu atau merasa senang. Hal ini disebabkan oleh penggunaan verba bantu memberi yang lain yaitu teyaru yang melekat pada verba inti homeru.

\section{4.*雨が＼cjkstart降ってくれた。(IH:145) \\ Ame ga futte kureta \\ Hujan Nom turun memberi \\ 'Hujan turun (untuk saya)'}

Kalimat 4 di atas tidak berterima secara makna, jadi tidak dapat digunakan, karena pemberi yaitu hujan (alam) adalah benda mati 無生物 yang tidak mungkin memberikan kebaikan secara sewajarnya / sepatutnya, atau mempunyai hasrat / keinginan untuk memberikan sesuatu kepada siapa pun.

\subsection{Kalimat yang menggunakan verba bantu menerima temorau}

Seperti telah dijelaskan sebelumnya bahwa untuk kalimat yang menggunakan tekureru dan temorau yang menjadi penerima kebaikan atau keuntungan adalah penutur atau pembicara. Perhatikan kalimat berikut : 
1.a.太郎 は 私 に 手伝ってくれた. (IH: 146)

Tarou wa watashi ni tetsudatte kureta

Tarou top saya kepada membantu memberi

'Tarou memberi bantuan kepada saya'

b. 私 は 太郎 に 手伝ってもらった. (IH: 145)

Watashi wa Tarou ni tetsudatte moratta

Saya top Tarou oleh membantu menerima

'Saya menerima bantuan dari Taro'.

Kalimat 1a menggunakan verba bantu memberi tekureru dalam bentuk lampau biasa, yang dilekatkan dengan verba inti tetsudau 'membantu' menjadi tetsudattekureta. Pemberi pada kalimat ini dijadikan sebagai fokus pembicaraan yang ditandai dengan joshi 'kata bantu' wa dan pembicara watashi 'saya' di sini menggunakan joshi 'kata bantu' penanda benefaktif/datif yang dapat diterjemahkan menjadi 'kepada' dalam bahasa Indonesia, sehingga jika diterjemahkan ke dalam bahasa Indonesia menjadi 'Tarou memberi bantuan kepada saya'. Lain halnya jika watashi 'saya' sebagai penerima ditandai dengan joshi 'kata bantu' o, maka terjemahan dalam bahasa Indonesianya akan menjadi 'Taro membantu saya', karena pemarkah o merupakan pemarkah untuk objek langsung. Penerima onkei 'kebaikan' dan penerima benefit adalah orang yang sama yaitu watashi 'saya' yang diberikan oleh seseorang yang bernama Tarou, dan yang diberikan berupa bantuan atau perpindahan jasa.

Kalimat $1 b$ menggunakan verba bantu menerima temorau, dan merupakan kalimat yang hanya mengubah posisi si penerima menjadi di awal kalimat sebagai fokus pembicaraan, dan pemberi diposisikan di tengah yang ditandai dengan joshi 'kata bantu' ni. Jika diterjemahkan ke dalam bahasa Indonesia menjadi 'Saya menerima bantuan dari Tarou'. Penerima yaitu watashi 'saya' sebagai penutur/pembicara diposisikan di awal kalimat yang ditandai dengan joshi 'kata bantu' wa. Penerima onkei dan benefit adalah orang yang sama, yaitu penutur / pembicara.

\section{2. a. 太郎 が 息子 を 裹めてくれた. (IH: 145)}

Tarou ga musuko o hometekureta

Tarou Nom anak laki-laki akus memuji memberi

'Tarou memuji anak laki-laki saya'.

\section{b. 太郎 に 息子 を 裹めてもらった。(IH:145) \\ Tarou ni musuko o homete moratta \\ Tarou Ben anak laki-laki akus memuji menerima \\ 'Anak laki-laki saya dipuji oleh Tarou'.}

Berbeda dengan kalimat 1a, data kalimat 2a menggunakan verba bantu memberi tekureru yang dilekatkan dengan verba inti homeru 'memuji' dengan penerima onkei bukan penutur / pembicara secara langsung, tetapi seseorang yang terkait secara uchi 'sekelompok/sekerabat' dengan penutur/pembicara, 
yaitu anak laki-laki penutur / pembicara musuko yang ditandai dengan joshi 'kata bantu' o. Jadi, penutur menerima onkei secara tidak langsung karena seseorang yaitu Tarou, yang ditandai dengan joshi 'kata bantu' ga, memuji anak lakilakinya. Jika diterjemahkan ke dalam bahasa Indonesia akan menjadi 'Tarou memuji anak saya', makna verba bantu memberi tekurerunya lesap.

Selanjutnya data kalimat $2 \mathrm{~b}$ menggunakan verba bantu menerima temorau yang dilekatkan dengan verba inti homeru 'memuji'. Penerima onkei 'kebaikan' yaitu musuko tetap ditandai dengan joshi 'kata bantu' o dan menyertai verba hometemoratta, sementara pemberi yaitu Tarou diletakkan di awal kalimat ditandai dengan joshi 'kata bantu' ni 'dari/oleh'. Pada kalimat ini pun penutur/pembicara merupakan penerima onkei 'kebaikan' secara tidak langsung karena kaitannya dengan musuko 'anak laki-laki' yang berada dalam kelompok uchi 'dalam'. Dan jika diterjemahkan ke dalam bahasa Indonesia akan menjadi 'Anak laki-laki saya dipuji oelh Tarou'.

\section{PENUTUP}

Verba bantu memberi tekureru dan verba bantu menerima temorau, keduanya memfokuskan pada hal penerimaan, yaitu adanya perpindahan barang, jasa, perasaan, ataupun kebaikan lainnya dari seseorang kepada orang lain, dan verba tekureru juga temorau ini menunjukkan hal penerimaan, yang diungkapkan oleh penutur/pembicara sebagai penerimanya, baik secara langsung diterima maupun secara tidak langsung. Untuk pemahaman dalam bahasa Indonesia, makna verba tekureru dan temoraunya bisa muncul dan bisa juga lesap disesuaikan dengan joshi 'kata bantu' yang digunakan dalam kalimat tersebut.

\section{DAFTAR PUSTAKA}

Comrie, Bernard.1989. Language Universals and Linguistic Typology. Oxford : Basil Blackwell.

Cruse, Alan.2004. Meaning in Language. Oxford : Oxford Linguistics.

Djajasudarma, T. Fatimah.2010. Metode Linguistik, Ancangan Metode Penelitian dan Kajian. Bandung : PT. Refika Aditama.

Ito, Hiromi. 2010. Juju koubun ni okeru jueki to onkei oyobi teineisa - [tekureru] bun to [temorau] bun o chuushin toshite. Nihongogakuronshuu, dai 6 gou.

Iori, Isao, et.al. 2001 Chuujoukyuu o Oshieruhito no tame no Nihongo Bunpou Handobukku. Tokyo : 3A Corporation.

Koizumi Tamotsu.2007.Gengogaku Nyuumon. Tokyo: Taishuukan Shoten.

Kuno, Susumu. 1973. The Structure of the Japanese Language. Cambridge :

The MIT Press.

Masuoka, Takashi.1981. Semantics of Benefactive Construction in Japanese, Descriptive and Applied Linguistics, XIV, I.C.U.

2000. Nihongo no Bunpou no Shosou. Tokyo : Kuroshio Shuppan. 
Matsuo, Takanori. 2003. Onkei Hyougen no Nieihikaku-(tekureru) o Chuushin ni. Journal NII-Electronic Library Service.

Morita, Yoshiyuki. 2006. Nihongo Bunpou no Hassou. Tokyo : Hitsuji Shoubou

Tsujimura, Natsuko. 1996. An Introduction to Japanese Linguistics. United Kingdom: Balckwell Publishing.

Yamada, Toshihiro.2000-2008. Nihongo ni Okeru Benefaktibu no Kijutsuteki

Kenkyuu, Daigokai, Benefaktibu Koubun ni oite Sanyosha no Torukaku. Jurnal.

Yamamoto, Hiroko. 2002. [temorau] no kinou ni tsuite - [tekureru] to hikaku shite-. Nagoya : Nagoya Joshi Daigaku. 